\title{
W HARMONII \\ Z NATURA I KOSMOSEM? \\ O POEZJI ANTONIA COLINASA \\ I ZBIGNIEWA HERBERTA
}

\author{
Maria Judyta Woźniak \\ Uniwersytet Łódzki \\ Katedra Filologii Hiszpańskiej
}

\begin{abstract}
Streszczenie. Poezję hiszpańskiego pisarza Antonia Colinasa (ur. 1946) oraz Zbigniewa Herberta (1924-1998) łączy głęboka duchowa wspólnota, o której świadczy m.in. poszukiwanie harmonii w przyrodzie i kosmosie. Chociaż myśl poetycka obu twórców często biegnie w różnych kierunkach, komparatystyczna lektura stwarza sytuację dialogu, w którym ujawniają się zaskakujące nieraz podobieństwa i frapujące różnice. Kontemplacja natury i urządzenia wszechświata prowadzi obu pisarzy do wniosku, że świat w zasadzie nie jest ładem, a zamiast upragnionego sensu można w nim odnaleźć pustkę, która jednak dla Colinasa, w przeciwieństwie do Herberta, czasami objawia człowiekowi upragniony sens. Herbert widzi przede wszystkim wspólnotę cierpienia człowieka i natury, Colinas zaś we wszechobecnej śmierci potrafi dostrzec ślad pewnego porządku.
\end{abstract}

Słowa kluczowe: Antonio Colinas, Zbigniew Herbert, poezja współczesna, literatura porównawcza, harmonia. 


\title{
IN HARMONY WITH NATURE AND UNIVERSE? ON POEMS BY ANTONIO COLINAS AND ZBIGNIEW HERBERT
}

\begin{abstract}
There exists a deep spiritual union between poems by the Spanish author, Antonio Colinas (born 1946), and those written by Zbigniew Herbert (1924-1998), which is reflected by, among others, seeking harmony in nature and the universe. Although the poetic concept of the two authors often runs in various directions, a comparative analysis gives rise to a dialogue which reveals at some points surprising similarities and striking differences. When contemplating nature and arrangement of the universe both authors arrive at a conclusion that in fact the world is not an order, and what may be found in it, instead of the desired sense, is an emptiness which, however, for Colinas as opposed to Herbert, unveils the desired sense to the human being. What Herbert mostly sees is the union of suffering between the human being and nature, whereas Colinas can notice a trace of some order in the omnipresent death.
\end{abstract}

Keywords: Antonio Colinas, Zbigniew Herbert, contemporary poetry, comparative literature, harmony.

Pomimo wielu odmienności, odległości geograficznej i różnicy pokoleniowej, hiszpańskiego poetę Antonia Colinasa (ur. 1946) i Zbigniewa Herberta (1924-1998) łączy głęboka duchowa wspólnota. Pisarze najprawdopodobniej nie znali się osobiście ani nie czytali swoich wierszy, wzajemny wpływ jest zatem raczej niemożliwy. Do porównawczej lektury ich poezji inspiruje wspólna im obu tęsknota za harmonią, płynąca z potrzeby ładu i sensu, z pragnienia zrozumienia ludzkiego życia i otaczającego nas świata, dostrzeżenia jego prawdziwego, istotnego znaczenia. Podążając za tą tęsknotą, obaj poeci w szczególnie intensywny sposób szukali własnej dykcji. Ich poezja, wyrazista i znacząca, zasłużyła też na wiele prestiżowych nagród ${ }^{1}$. Warto również zauważyć, że obaj pisali w czasach, które chciały odnaleźć dla siebie nowe formy poetyckiego wyrazu: Colinas w epoce, która musiała zająć sta-

1 Colinas i Herbert to także prozaicy i tłumacze, o szerokich humanistycznych zainteresowaniach. 
nowisko wobec wcześniejszej „poesía social”, Herbert - w czasach powojennego krystalizowania się „dykcji nowej”.

Poezja omawianych twórców została już opisana z różnych perspektyw badawczych i stanowisk interpretacyjnych ${ }^{2}$, jednak komparatystyczna lektura pozwala na stworzenie szczególnej sytuacji dialogu, w którym nowy kontekst ujawnia to, co inaczej pozostałoby ukryte. Inspirujące poznawczo wydaje się takie podejście, o jakim mówi Teresa Kostkiewiczowa: „nieistotne jest to, czy istnieją faktyczne kontakty i powiązania między badanym dziełami czy konstruktami literackimi, ale ważne są podobieństwa, a więc paralelizmy, homologie, zbieżności, analogie, synchronizmy itd." (Kostkiewiczowa, 1998: 14). Oczywiście taka postawa zakłada w sposób nieunikniony subiektywność komparatystycznego przedsięwzięcia, zarówno w wyborze, jak i w interpretacji utworów poetyckich, na co jednak pozwala charakter współczesnych badań literaturoznawczych.

Tutaj interesować nas będzie poszukiwanie harmonii w otaczającej człowieka przyrodzie i w kosmosie. W tych przestrzeniach Colinas i Herbert szukają przede wszystkim odpowiedzi na pytanie o cierpienie, które dysonansem zakłóca harmonię świata. Zauważmy od razu, że zwykle poetyckie deklaracje Herberta są mniej jednoznaczne niż hiszpańskiego poety, a czytelnik musi pamiętać o charakterystycznej dla polskiego poety ironii, która często każe brać w nawias jego zapewnienia o istnieniu harmonii. Idylliczna harmonia z przyrodą i resztą świata jest Herbertowi zasadniczo obca, jak choćby w znanym wierszu Arijon, gdzie harmonia na kształt rajskiego ogrodu jest tylko pozorna. Z kolei u Colinasa entuzjazm dla zastanego porządku świata wydaje się oczywisty w początkach twórczości, później zaś, nawet jeśli na chwilę pojawia się poczucie harmonii, to zwykle towarzyszy mu świadomość cierpienia. Dążenie do akceptacji słabości i bólu jest wspólne obu poetom.

Jak zatem wyglądają te poetyckie poszukiwania harmonii w przyrodzie i kosmosie? Jakie pytania stawiają poeci i jakie odpowiedzi słyszą?

2 Dużo lepiej wydaje się jednak opisana i zbadana twórczość Herberta - ten stan badań oczywiście musiał znaleźć odzwierciedlenie w przywoływanej tutaj bibliografii. 
Wyjątkowo wyrazisty i dramatyczny jest wiersz Herberta Dęby, otwierający zbiór o pożegnalnym tytule Elegia na odejście 3 , w którym poeta porusza kwestie fundamentalne - od tego utworu zatem warto zacząć. Drzewo, uniwersalny symbol porządku świata, axis mundi, jest tutaj metaforą dramatu ludzkiego życia, w którym byt objawia się w całej swej intensywności i rozrzutności (Potkański, 2002: 30-31). Poruszane tematy należą do najogólniejszych i zarazem najbardziej istotnych - to pytania o tajemnicę narodzin, miłości, cierpienia:

W lesie na wydmie trzy dorodne dęby

u których szukam rady i pomocy

bo chóry milczą odeszli prorocy

nie ma na ziemi nikogo bardziej

godnego szacunku dlatego do was

kieruję - dęby - ciemne pytania

na wyrok losu czekam jak niegdyś w Dodonie

Lecz muszę wyznać że mnie niepokoi

wasz rytuał poczęcia - o rozumne -

u schyłku wiosny na początku lata

w cieniu konarów roi się

od waszych dzieci i niemowląt

przytułki listków sierocińce kiełków

blade bardzo blade

słabsze od trawy

na oceanie piasku

walczą samotnie samotnie

dlaczego nie bronicie waszych dzieci

na które pierwszy mróz położy miecz zagłady

Szukanie pomocy u wyroczni („na wyrok losu czekam jak niegdyś w Dodonie”) oznacza imitację antycznego gestu, a więc jedynie pozorne poszukiwanie pierwotnych źródeł poznania,

3 Podaję tytuły tomów tam, gdzie jest to szczególnie istotne, na przykład ze względu na ewolucję myśli poety - powstanie utworu we wczesnym lub późniejszym okresie twórczości. Podobnie postępuję, jeśli chodzi o tytuły tomów poetyckich Colinasa. 
jak zauważa trafnie Andrzej Franaszek (2008: 171) ${ }^{4}$. Cierpienie w przyrodzie nie daje się więc uzasadnić w żaden sposób - ani moralnie, ani religijnie. Na bezradne pytanie:

Jak mam rozumieć waszą mroczną parabolę [...]

Życie na oślep zmieszane ze śmiercią

odpowiedzią jest brak sensu i celu, a rezultatem - głęboka rozpacz zapisana w ostatnich wersach:

tyle liści a pod każdym liściem

Tyle pytań - o dęby -

rozpacz

Franaszek formułuje słuszny, choć radykalny wniosek: „Wiersz otwierający Elegię na odejście podważa wszelkie nadzieje na odkrycie w świecie nadrzędnego ładu” (Franaszek, 2008: 176). Podważa, choć ostatecznie ich nie porzuca ${ }^{5}$.

Dęby nie są wyjątkowym ani odosobnionym wyrazem bezradnej rozpaczy w poezji Herberta. W umieszczonym kilka stron dalej wierszu Rodzina „Nepenthes” poeta konsekwentnie odcina

4 Nieco dalej Franaszek pisze: „Dęby są więc destrukcją harmonijnego, zakładającego teleologiczny ład, obrazu świata" (2008: 174). Inaczej czyta ten wiersz Stanisław Barańczak, który uważa, że w poezji Herberta sens życia i świata jest człowiekowi mimo wszystko dany, a sprowadza się on do wartości samego istnienia i do wartości ludzkiej odpowiedzialności (zob. Barańczak, 2001: 187; zob. też: Fiut, 2000).

5 Warto dopowiedzieć, że zakończenie wiersza nie rozstrzyga jednoznacznie, o czyjej rozpaczy tutaj mowa, pozwalając na różne odczytania. Kwestię tę próbuje skonkretyzować Karolina Górniak, kiedy wspomina o trzech możliwych tropach interpretacyjnych: oprócz analogii między przyrodą a naturą skazanego na cierpienie człowieka można tu dostrzec niepewność eschatologiczną czy nawet nawiązanie do sytuacji jednostki w świecie, w którym „w relacjach międzyludzkich prawo siły stawia się ponad wartościami humanistycznymi" (Górniak, 2015: 189). 
się od szukania w przyrodzie fałszywego ukojenia, podkreślając swą odrębność od postawy Rousseau, nazwanego tutaj Janem Jakubem Tkliwym:

Czy Jan Jakub Tkliwy wiedział coś o dzbaneczniku - powinien wiedzieć roślinę opisał Linneusz więc dlaczego przemilczał ten skandal Natury

jeden $\mathrm{z}$ wielu skandali a może to było ponad wydolność serca i gruczołów łzowych tego który w przyrodzie szukał ukojenia

Konkluzja nie może być inna:

a my żyjemy z dzbanecznikiem w zgodzie wśród łagrów i kacetów mało nas obchodzi wiedza że w świecie roślin niewinności - nie ma

U Herberta pytanie o ostateczny sens bólu i jego wszechobecność pozostaje bez odpowiedzi, bo nawet najbardziej uniwersalny mit nie obejmie istoty wszelkiego cierpienia. Jego nieuchronność pokazują na przykład wiersze Mały ptaszek, Koń wodny czy Tarnina.

Najdobitniej jednak bezsens cierpienia wyraża symbol sekwoi (Sekwoja z tomu Pan Cogito). Słoje drzewa, powstałe w różnych momentach dziejów, zapisują okrucieństwo historii. W kolejnych wersach okazuje się, że „gotyckie wieże z igliwia w dolinie potoku”:

[...] pokazują przekrój drzewa miedziany pień zachodu o słojach niezmiernie regularnych jak kręgi na wodzie i ktoś przewrotny wpisał daty ludzkiej historii cal od środka pnia pożar dalekiego Rzymu za czasów Nerona w połowie bitwa pod Hastings nocna wyprawa drakkarów popłoch Anglosaksonów śmierć nieszczęsnego Harolda opowiedziana jest cyrklem i wreszcie tuż przy wybrzeżu kory lądowanie Aliantów w Normandii

Tacyt tego drzewa był geometrą nie znał przymiotników nie znał składni wyrażającej przerażenie nie znał żadnych słów 
więc liczył dodawał lata i wieki jakby chciał powiedzieć że nie ma nic poza narodzinami i śmiercią nic tylko narodziny i śmierć a wewnątrz krwawa miazga sekwoi

Bohater tego wiersza, jak komentuje Danuta Opacka-Walasek (2005: 124):

Wychodząc od opisu aktualnego stanu przestrzeni, wskazuje wpierw na jej łudzącą harmonię, symbolicznie uwydatnioną idealnym, kolistym kształtem: oto słoje sekwoi są „niezmiernie regularne jak kręgi na wodzie”, a uporządkowana historia „opowiedziana jest cyrklem”. Dopiero spojrzenie diachroniczne, rekonstruujące dzieje, daje właściwy wgląd w ich istotę. Wydobywa ironiczną niewspółmierność aktualnego obrazu w stosunku do jego treści: symetryczne kręgi mogą łudzić doskonałością, a w rzeczy samej historia jest chaotyczna, absurdalna, okrutna ${ }^{6}$.

W porządku historycznym śmierć i cierpienie nie mają żadnego sensu.

Do innych wniosków dochodzi hiszpański poeta, kiedy stawia podobne pytania w porządku egzystencjalnym. Colinas, myśląc o naturalnym cyklu życia i śmierci, często podkreśla paradoksalnie życiodajną siłę śmierci. W Traktatach o harmonii (2010: 32-33) pisze:

Prawda przyrody, prawda życia... Ciągły wzrost i śmierć, niezmordowane kwitnienie i niewyczerpane zniszczenie. To było tak, jakby śmierć jednych roślin dawała młodość innym. Rosnąć i umierać bezustannie i cyklicznie. Nie znalazłem innej prawdy bardziej rzeczywistej, bardziej uchwytnej, piękniejszej i straszliwszej w głębokościach doliny?

6 Wspólnym rysem natury i historii jest nieusuwalna obecność w nich cierpienia oraz obojętność na losy człowieka. Opacka-Walasek dodaje jeszcze, że „geometra historii” z omawianego wiersza „żywo przypomina siłę sprawczą z Dębów” (2005: 125).

7 Przekład z języka hiszpańskiego, tego i następnych cytatów: M. J. Woźniak. Przedstawione tłumaczenia poezji mają na celu 
Colinas wysnuwa z tej obserwacji jeszcze dalej idące wnioski. Otóż naturalna cykliczność życia może według poety przynosić poczucie pewnego i trwałego porządku świata ${ }^{8}$. Samo istnienie tego porządku zdaje się wystarczać za uzasadnienie ludzkich cierpień. Jeśli bowiem „człowiek jest światem w miniaturze” (Colinas cytuje Demokryta; Colinas, 2010: 224), to również świat odzwierciedla kondycję człowieka - jeśli w naturze w życie wpisana jest śmierć, to także w ludzkiej egzystencji musi mieć ona swe miejsce i cel.

W wierszu En el bosque, podobnie jak w utworze Herberta naśladującego starożytny gest, bohater kieruje do drzew bezradne pytania:

¿De dónde nace este clamor del bosque?

¿Es el clamor del silencio?

¿Es un clamor de muerte?

[Skąd pochodzi ten krzyk lasu?

To krzyk ciszy?

Czy jakiś krzyk śmierci?]

Las dla Colinasa jest przestrzenią, w której objawia się jedyna istniejąca prawda, piękna i straszna zarazem prawda o cyklicznym prawie wzrostu i zepsucia. Szczególnie drzewo jest symbolem tego dwoistego przesłania: wszystko się zmienia, wszystko jest tylko etapem w życiu człowieka (Colinas, 1990: 35).

Na postawione na początku wiersza pytania dalszy ciąg nie daje jednak odpowiedzi. Najpewniej po prostu jej brak, zaś krzyk wyraża zarówno ból śmierci, jak i życia. O utajonej obecności tej pierwszej przypominają jednak niektóre odgłosy i obrazy: rozlegają się jakieś ostre dźwięki czy wystrzały, leżą martwe zwierzęta.

Dopełnienie sensu wiersza En el bosque znajdziemy w innym utworze Colinasa - La encina ( $D a b$ ). Jego bohater - znów podob-

przede wszystkim możliwie wierne zapoznanie czytelnika $\mathrm{z}$ istotnym przekazem utworów, nie są to tłumaczenia artystyczne.

8 Pod tym względem Colinas podkreśla swoje związki z taoizmem. 
nie jak w wierszu Herberta i znów na wzór starożytnych - przychodzi do dębu: „a tutaj obok mnie jest tylko dąb / stary i czarny, ogromny i poważny” („y aquí a mi lado sólo hay una encina / vieja y negra, enorme y grave"), pod którym chce się schronić. Jednak zamiast chronić, drzewo przede wszystkim budzi niepokój, prowokując do zadawania gorzkich egzystencjalnych pytań:

¿Qué podría yo hacer en este espacio con esta encina-madre, con esta compañera

de grandes brazos negros, de grandes brazos duros, con este candelabro de velas apagadas?

¿Comeré de sus frutos más amargos?

Y, si tiendo los brazos, ¿sentiré cómo hiere

su hojarasca de escarcha?

[Co ja mógłbym zrobić w tej przestrzeni

$\mathrm{z}$ tym dębem-matką, z tą towarzyszką

o wielkich czarnych ramionach, o wielkich twardych ramionach, $\mathrm{z}$ tym kandelabrem zgaszonych świec?

Będę jadł owoce tak gorzkie?

A skoro wyciągam ramiona, poczuję jak ranią

twoje liście ze szronu?]

Poeta przeczuwa, że przyroda - symbolizowana przez „czarny dąb” i jego gorzkie owoce - zna jakąś tajemnicę. Wobec niej bohater odczuwa ból egzystencjalnej samotności, podobnie przecież jak w cytowanym En el bosque. Pomimo to Colinas zawsze ma nadzieję, że porządek natury może być ocaleniem przed chaosem - o trwałości tej nadziei świadczą na przykład początkowe wersy utworu z tomu Canciones para una música silente, wydanego kilka lat temu (XXV utworu z cyklu Un verano en Arabí): „Widzę, że wobec chaosu zasadziłeś na swym tarasie i wyrosły dwa piękne cyprysy" („Veo que, frente al caos, / plantaste en tu terraza y han crecido / dos hermosos cipreses").

Do jakich ostatecznie wniosków prowadzi obserwacja świata natury? Herbert we współuczestnictwie przyrody w ludzkich cier-

9 W tłumaczeniu starano się oddać potoczną składnię oryginału. 
pieniach, bez końca się odnawiających, widzi świadectwo wspólnoty istnienia, o której stanowi przede wszystkim brak nadrzędnego sensu i celu. Łączność w cierpieniu jednak wcale nie musi oznaczać solidarności i współczucia, ponieważ przyroda nie koi dramatycznego poczucia samotności. „Zostać w porządku natury" to zyskać świadomość przynależności do takiej natury, którą przenika cierpienie, a celem wydaje się śmierć. Natomiast obraz przyrody w poezji Colinasa daje człowiekowi pewną nadzieję. Świadomy dramatyzmu ludzkiej kondycji, znajdującej swe odbicie w świecie natury, hiszpański poeta widzi śmierć nade wszystko jako nieodłączny warunek ciągle odnawiającego się życia.

Podobne pytania o ludzką kondycję i sens cierpienia stawiają poeci również wtedy, gdy przyglądają się urządzeniu kosmosu.

W zbiorze esejów Herberta Martwa natura $z$ wędzidłem narrator wspomina o astronomach, którzy „odkrywają architekturę wszechświata, wolę Wiekuistego i prawa Harmonii” (Herbert, 1993: 150). I Colinas, i Herbert próbują pójść ich śladem, bacznie przyglądając się urządzeniu świata i domagając się dowodów na to, że człowiek może pozostać w harmonii z kosmosem ${ }^{10}$. Warto przy tym zauważyć, że taka koncepcja świata ma dużo wspólnego z mityczną wizją rzeczywistości postrzeganej jako całość ${ }^{11}$ - to wspólna cecha myślenia obu poetów.

W czterech pierwszych tomach hiszpańskiego poety wszechświat jest w zasadzie bytem harmonijnym, ale już w Sepulcro de Tarquinia, od cyklu Castra Petavonium, obserwacji kosmosu towarzyszy przeczucie, że ostatecznego ładu nie ma ${ }^{12}$. Kontemplacja kosmicznego porządku, która w pierwszych tomach prowadziła do radosnego zachwytu harmonią, teraz często budzi nie-

10 Zob. też: Marí, 1990: 57.

11 Jak zauważa Henryk Markiewicz, cechą myślenia mitycznego jest postrzeganie całości izomorficznej na różnych poziomach jej organizacji (na przykład ciało ludzkie, ziemia, przestrzeń kosmiczna; Markiewicz, 1989: 67).

12 Szczególnie jednak w tomie Astrolabio odwołania kulturowe ustąpiły niespokojnym pytaniom inspirowanym przez naturę (zob. Cano, 1982: 7). 
pokój. Jednak sama idea kosmicznego ładu nie została przez poetę odrzucona. Choć rzeczywistość często jej zaprzecza i wydaje się rządzona przez chaos (Alonso Gutiérrez, 2000: 64), poeta pragnie wierzyć, że istnieje jakaś siła wyższa, która wprowadza harmonię, widoczna w doskonałym ruchu ciał niebieskich (Marí, 1990: 57). „Ktoś płacze tam w górze” („Alguien está llorando allá arriba”) - mówi w ostatnim swym tomie - nad nami, którzy nie znamy ostatecznego sensu życia i nie jesteśmy w pełni sobą (wiersz XXIX cyklu Un verano en Arabí z tomu Canciones para una música silente). Czy jednak taka daleka obecność może ostatecznie zaradzić dręczącemu poczuciu samotności? Doświadczenie zarazem pustki, jak i przeczucie obecności Absolutu świadczą o uwikłaniu człowieka w przeciwieństwa, które bohater Colinasa dramatycznie próbuje pogodzić. Pomimo tego, że sceptycyzm często nie pozwala już na jednoznacznie afirmatywny gest wobec urządzenia świata, a fundamentalne pytania pozostają bez odpowiedzi, „nasz głód jest niebieski13, oczy utkwione w górze” („Nuestra hambre es celeste, se nos quedan los ojos allá arriba") - mówi w wierszu Laderas de Peña Trevinca.

Gwieździste niebo, wcześniej źródło inspiracji, dające pokój kojący metafizyczny ból człowieka (jak u Novalisa), w tomie Astrolabio staje się czymś przeciwnym. Nie tylko nie daje odpowiedzi, ale uświadamia istnienie pustki, wielkiej pustki kosmicznej, i nasuwa nowe dręczące pytania. W wierszu Canto I, otwierającym tom Noche más allá de la noche, czytamy:

¿Qué secretos oculta, arriba, el cosmos que arde sobre la muerte y qué nos reserva el acaso?

[Jakie sekrety skrywa w górze kosmos, który płonie nad śmiercią i co gotuje nam los?]

Do najtrudniejszych kwestii należy zasadnicze pytanie o własną tożsamość wobec wszechświata, wyrażone wprost w wierszu Canto XXVII:

13 W znaczeniu: dotyczący nieba. 
“¿Y yo quién soy?”, pregunta en el centro del Todo un cuerpo que recuerda a la nada

[„A ja kim jestem?”, pyta w środku Wszystkiego

ciało, które przypomina pustkę]

Człowiek współczesny, który - jak pisze Colinas - skupiony na doraźnej codzienności, już „do gwiazd nie wyciąga rąk” (Poseidonia, vencedora del tempo), nie potrafi rozpoznać, kim jest. Retoryczne pytania z Canto I świadczą o zagubieniu w chaotycznej rzeczywistości:

[...] Pues, ¿por qué se da guerra

junto a amor y por qué la voz de la ebriedad

y el dolor infinito van girando en la tierra?

[Więc dlaczego wojna wybucha

obok miłości i dlaczego głos upojenia

i nieskończony ból wciąż krążą po ziemi?]

Pytania zapisane w tym wierszu, także obecne w twórczości Herberta, w poezji Colinasa stają się niemal obsesyjne. José Olivio Jiménez stwierdza wręcz, że cały tom Noche más allá de la noche koncentruje się „wokół tego dręczącego niepokoju, który pochodzi z nieznajomości własnego losu” (Jiménez, 1984: 40). Skłania do tego niemożliwość zrozumienia wszechświata, który jest zarazem piękny, tajemniczy i straszny. Nigdy jednak nie prowadzi to Colinasa do poczucia absurdu egzystencji - przeciwnie, tym usilniej motywuje go do nieustannych poszukiwań.

Próbując ocalić nadzieję, Colinas docenia ogrom i nieskończoność niewyczerpanego kosmosu, tak różne od zmienności człowieka, żyjącego w czasie historycznym (Alonso Gutiérrez, 1990: 101). W wierszu Jardín-Leteo mówi:

Pero aquí todo es mudable y fugitivo: el jardín del estío, la soledad del lobo, la estatua y su espacio, delfines, el desierto... Fuente de nuestros días, ola inagotable es este firmamento tan inmenso. 
¿Y la Historia qué es, qué supone la Historia?

La Historia sólo es ese pozo del huerto,

un pozo sin secretos, cegado,

con rebaños eternos, al final de un sendero.

[Ale tutaj wszystko jest zmienne i ulotne:

letni ogród, samotność wilka,

pomnik i przestrzeń, delfiny, pustynia...

Źródłem naszych dni, niewyczerpaną falą

jest ten ogromny firmament.

A czym jest Historia, co oznacza Historia?

Historia jest tylko studnią w ogrodzie,

studnią bez tajemnic, zamkniętą,

z odwiecznymi stadami, na końcu ścieżki.]

Historia pokazuje, że mijający czas nie przynosi poczucia sensu, lecz jedynie nowe cierpienia. „Czas przemija lecz nie zmienia” - pamiętamy z Herbertowskiego wiersza Mój ojciec ze Struny światła. Człowiek nie tylko nie wykorzystał mijającego czasu, by rozwiązać swe najważniejsze problemy, ale również zdewaluowało się to, co osiągnął - została „pustka wieków” (Megalítico z tomu Astrolabio). Osiągnięcia starożytnych, które miały być lekarstwem na wszystkie trudy życia, okazały się złudną nadzieją.

Wobec tych rozczarowań nieznany ogrom kosmosu jednak nie przyniesie nadziei, jak podkreśla Herbert. W wierszu Do Marka Aurelego (z tomu Struna światła) polemizuje ze starożytną postawą stoicką, której nie sposób pogodzić z ludzkim cierpieniem ${ }^{14}$. W świat odwiecznie wpisany jest lęk, nie stoickie mądrości, o których czyta w księgach cesarz-filozof. To doświadczenie staje się udziałem barbarzyńców, którym nie grozi zagubienie w intelektualnych subtelnościach:

14 Wiersz Do Marka Aurelego Przybylski nazywa „śmiertelnym pchnięciem, które ugodziło w stoicką ideę wewnętrznej harmonii umysłu” (Przybylski, 1998: 80). Z kolei za „najbardziej stoicki wiersz" Herberta - wedle określenia Wojciecha Ligęzy (2001: 32) - można by uznać Dojrzałość (z tomu Hermes, pies i gwiazda): Seneka, „miły staruszek”, który choć „ujmującym gestem zaprasza”, dla współczesnych jest symbolem rezygnacji i śmierci. 
to niebo mówi obcą mową

to barbarzyński okrzyk trwogi

którego nie zna twa łacina

W świecie Herbertowskim, w którym żyje drapieżny koń wodny i owadożerny dzbanecznik (Koń wodny, Rodzina „Nepenthes”), kosmos nie może ułożyć się już - jak niegdyś dla Marka Aureliusza w pełną ładu, celowo urządzoną całość, której człowiek jest po prostu harmonijnym elementem. Herbert, jak pisze Lisicki (1998: 255),

żyje [...] z pełną świadomością, że grecki wszechświat ostatecznie się rozpadł. Nie jest już wszechprzenikającym ładem, ale chaosem pozbawionym ludzkiego znaczenia, od człowieka oddzielonym.

„Od stoika - zauważa Aleksander Fiut - który szukał oparcia w harmonii wszechświata, [Herbert] domaga się, by usłyszał gwiazdy bijące na trwoge” (Fiut, 2000: 286). „Srebrne larum gwiazd" wznosi się nad śmiercią 15 . W poemacie Colinasa Sepulcro de Tarquinia cała nasza galaktyka jest przedstawiona jako towarzyszka ludzkiego cierpienia: „La Vía Láctea crujía si llorabas” („Droga Mleczna skrzypiała, kiedy płakałeś”). Gwiazdy współuczestniczą w śmierci (Jiménez, 1984: 40). O „bardzo starym” lęku czytamy także w Los cantos de ónice VI:

Cada hombre transporta en sí gotas de un miedo

muy antiguo

que, irremediablemente,

acaba estallando.

[Każdy człowiek nosi w sobie krople lęku

bardzo starego,

który nieuchronnie

w końcu wybucha.]

15 Kolor srebrny w poetyckiej wyobraźni Herberta często odnosi się do śmierci. Zob. na przykład wiersz Hotel: „widzimy jak na miejscu twarzy pojawia się srebrna pleśń". 
Odległe niebo mówi człowiekowi, że porządkiem świata rządzi śmierć i lęk. „Istnieje ból” („Existe el dolor”), mówi poeta prosto i lapidarnie w ostatnim tomie (Llamas en la morada IX z tomu Canciones para una música silente).

W poetyckim świecie Herberta, jak w liryce Rilkego, śmierć jest wpisana w nasze życie już od urodzenia, jest w nas od zawsze (zob. Franaszek, 2008: 177-178). W wielu wierszach polskiego poety dochodzi do głosu ponura świadomość jej skrytej obecności, zbliżania się, pracowitego i niedostrzegalnego, na wzór krzątaniny mrówek w prozie poetyckiej Zegarek na rękę z tomu Napis. O „śmierci pospolitej”, „bezradnym białym mrówczym jaju" wspomina inny utwór z tego samego tomu (Śmierć pospolita). Śmierć jest tak głęboko wpisana w człowieka, jak pierwotne lęki, odziedziczone po przedhistorycznych przodkach (Pan Cogito obserwuje w lustrze swoją twarz). „Sens cierpienia, sens ścierania się z rzeczywistością - to cała sprawa" (cyt. za Franaszek, 2008: 41) - mówił o sensie w poezji Herbert. Jedynym remedium, jakie proponuje Herbertowski wiersz Do Marka Aurelego, może stać się bliskość drugiego człowieka, tak samo słabego i ograniczonego:

więc lepiej Marku spokój zdejm

i ponad ciemność podaj rękę

niech drży gdy bije zmysłów pięć

jak w wątłą lirę ślepy wszechświat

Poeta pozostawia człowieka z jego płaczem, z poczuciem opuszczenia i zdrady, ale i z odrobiną nadziei, że gest podania ręki przyniesie ulgę.

Z utworem Do Marka Aurelego zadziwiająco koresponduje cykl dwóch wierszy Colinasa Del vacío del mundo (Retrato i wspomniany już utwór Megalítico). Łączy je przede wszystkim artykulacja głębokiego lęku egzystencjalnego i przerażenia niezrozumiałym kosmosem.

W pierwszym z nich, Retrato, Colinas szkicuje portret człowieka współczesnego - jego tragiczną twarz istoty bezradnej wobec potężniejszych sił. Człowiek ów nie płacze sentymentalnymi łzami, nie użala się nad własnym losem. Płacze jak osoba doj- 
rzała, która zna i uczciwie ocenia swoje możliwości wobec okrucieństwa świata. Płacz zdradza prawdziwą naturę człowieka - jak w ostatnim wersie Do Marka Aurelego (,i mój bezradny Marku płacz”). Retrato pokazuje chwilę brutalnego uświadomienia sobie własnego losu, uczestnictwa w świecie udręczonym, którego nie można zrozumieć. W drugiej części wiersza na ręce człowieka spada ogień lub popiół (wiersz pozostawia wątpliwość), wymownie obrazujący ulotność i znikomość ludzkiego życia. Krajobraz spalonych i wapiennych ${ }^{16}$, a więc martwych, wzgórz przywodzi na myśl śmierć, opuszczenie i ból. Przypomina się Canto $X$, gdzie umierający wypowiada takie słowa:

No quiero que me entierren bajo un cielo de lodo, que estas sierras $\tan$ hoscas calcinen mi memoria.

[Nie chcę, żeby mnie pochowano pod niebem $\mathrm{z}$ błota, żeby te góry tak posępne zwapniły moją pamięć.]

Choć w wielu miejscach hiszpański poeta wyraża wprost uczucia, tutaj jednak lęk i przerażenie jedynie sugeruje budowanymi stopniowo obrazami. Kosmos to straszny, nieludzki mechanizm („atroz mecánica”), skomplikowana maszyneria nieba („complicada maquinaria celeste”). Odmierzany przez ten mechanizm czas bezlitośnie płynie, potęgując cierpienia.

Drugi wiersz wspomnianego cyklu, Megalítico ${ }^{17}$, wyraża zdumienie współczesnego człowieka przyglądającego się szalonym gestom neolitycznych przodków, którzy precyzyjnie, pod ściśle odmierzonym kątem, ustawiali ogromne skały. Nie rozumie on tajemniczego ułożenia kamieni, nie dostrzega celowości w sta-

16 Również w poezji Herberta symbolika wapna odsyła do śmierci.

17 Oznacza to „megalityczny”, co odnosi się do megalitu (z gr. megas litos). Megality to nieobrobione lub częściowo obrobione kamienie, które ustawiano już w czasach prehistorycznych, pojedynczo albo jako część większej całości, w celach niewyjaśnionych do końca przez naukowców - niektóre z nich były przeznaczone do kultu, czasem wykorzystywano je w celach astronomicznych. 
rannie wykutych otworach. W wierszu Colinasa taki megalit podtrzymuje niebo - „dach nocy”, jest istotą żywą, podległą prawom biologii. Wysiłek powoduje niewypowiedziane cierpienie („esa enorme piedra torturada” - „ta ogromna udręczona skała”; „esta enfebrecida carne” - „to rozgorączkowane ciało”). Człowiek - uważa poeta - jak ów kamień, usiłuje być odporny i niezniszczalny. Nie ma na to jednak szans, bo świat, w którym żyje, za bardzo go rani. Marek Aureliusz, cesarz rzymski przywołany przez Herberta, zalecał: „Podobny bądź do skały, o którą się ciągle fale rozbijają. A ona stoi" (cyt. za Fiut, 2000: 187). Człowiek-skała stoi, ale jaką cenę za to płaci! Jest samotny wobec wielkiego świata - jak u Salvatore’a Quasimodo, którego poezję Colinas cenił i przekładał na hiszpański:

Każdy stoi sam na sercu ziemi przeszyty promieniem słońca. I nagle jest wieczór ${ }^{18}$

Człowiek więc przez całe stulecia nie odnalazł właściwego kierunku. Choć próbował tysiące lat temu, stawiając megality, od wieków ćwicząc się w stoickiej obojętności, nie znalazł odpowiedzi wobec rozciągającej się nad nim pustki kosmosu. W wierszu Otoñal mówi poeta: „inmenso es el silencio, / el vacío del mundo” („ogromna jest cisza, / pustka świata”). Ta pustka, stara jak ludzkość i jej lęk, może oznaczać tutaj brak nadrzędnego bytu, Absolutu, rękojmi sensu, zakorzenienia, możliwości schronienia przed dostrzeganym chaosem. Zamiast tego - „congelación celeste": mróz w świecie, zmarzlina. Ciekawe, że również w wierszu Herberta Zobacz (z tomu Struna światła) błękit jest „zimny jak kamień o który ostrzą skrzydła / aniołowie wyniośli i bardzo

18 Wiersz cytuję w przekładzie Barbary Stelmaszczyk (2001: 322). Autorka przywołuje utwór włoskiego poety, opisując lapidarną dykcję Herberta w wierszu Koniec. Herbert mówi w nim o śmierci, która nagle i nieodwołalnie usuwa człowieka spośród żyjących, co sugestywnie zilustrują w przyszłości zdjęcia zbiorowe. Rzeczywiście - w utworach obu poetów, polskiego i włoskiego, oszczędne środki poetyckie przejmująco wyrażają definitywność śmierci. 
nieziemscy". Człowiek odczuwa przede wszystkim przejmujący chłód kosmosu - w niebie jest zimno i nieludzko. Puste niebo, obce ludziom, obrazuje zarazem wewnętrzną pustkę człowieka, którą nosi on w sobie zamiast udzielać odpowiedzi na najistotniejsze pytania (zob. Alonso Gutiérrez, 2000: 65) ${ }^{19}$.

Trzeba również zauważyć tutaj, że dla Colinasa kosmiczna pustka może konotować diametralnie odmienne znaczenia, stając się przedmiotem pożądania. Otóż doświadczenie pustki bywa dla niego równoznaczne z harmonijną jednością wszystkich elementów kosmosu, z osiągnięciem czystej kontemplacji (Sepúlveda, 1997: 242). Nie tylko zmysłowe, lecz także „intelektualne oczyszczenie" jest warunkiem głębszego poznania. Mówi o tym na przykład w Canto XX (z Noche más allá de la noche) czy w Junto al Huécar (z Los silencios de fuego), za źródło poznania podając „nic”, oczyszczenie, pustkę. Colinas potrafi - paradoksalnie, jak mistycy - odnaleźć w pustce pełnię, odwołując się do taoizmu oraz pitagorejczyków i Platona, dla których harmonia rodziła się w walce przeciwieństw. Hiszpański poeta szuka takiego „nic”, które byłoby wszystkim (na przykład w wierszu Tántalo contra Sísifo z tego samego tomu). Rzeczywistość zaświatów jest według niego harmonijna, to „la nada plena” - „pełne nic”. Dwuznaczne, trudne do oddania w przekładzie, takie wyobrażenie harmonii doskonale pokazuje jej paradoksalną naturę. Harmonia powinna godzić przeciwieństwa i niezależnie od ontologicznych założeń być spełnieniem odwiecznych pragnień ludzkości.

Natomiast w poezji Herberta pustka i nicość konsekwentnie pojawiają się w skojarzeniu z martwotą, śmiercią, nieobecnością $^{20}$. Przeraża poetę pustka zaświatów, ponieważ oznacza po-

19 U hiszpańskiego poety motyw "gwiezdnej pustki” powtarza się obsesyjnie, zwłaszcza w tomie Astrolabio, ale obecny jest również w kolejnych zbiorach.

20 Według Przemysława Czaplińskiego „ani niebo, ani historia, ani rozum nie dają poręki sensowności ludzkim działaniom. Całą egzystencjalną sytuację człowieka postrzega Herbert z tej samej perspektywy, którą nazwać można domysłem nicości” (Czapliński, 1998: 302). Wedle innego krytyka poeta zmaga się z „radykal- 
zbawienie człowieka wrażeń zmysłowych ${ }^{21}$. W wierszu Przeczucia eschatologiczne Pana Cogito kulminację cierpienia wyraża „trzebienie zmysłów” w poetycko wyobrażonym niebie: „komisja werbunkowa / pracuje bardzo dokładnie // trzebi ostatki zmysłów / kandydatów do raju".

Herbert wzbrania się też przed pustką rozumianą jako duchowe czy intelektualne ogołocenie. Z ironią mówi o bohaterze wiersza Pan Cogito a myśl czysta:

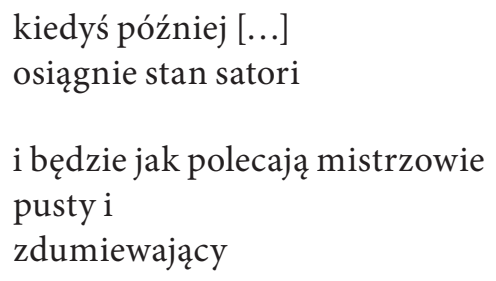

Kiedy to nastąpi? „Kiedy ostygnie”, czyli po śmierci. W późnym wierszu Telefon wyznaje:

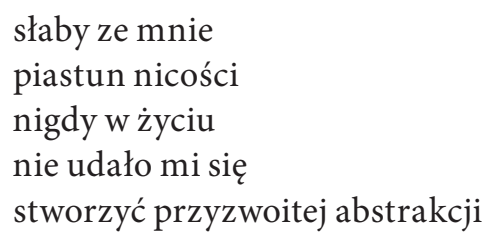

Słowa te padają po imaginacyjnej rozmowie $\mathrm{z}$ Thomasem Mertonem, przebywającym w Herbertowskim wierszu w zaświatach. Merton wszak twierdził: „dla mnie pustka to pełnia”. Kiedy więc poeta zapowiada: „będę siedział / nieruchomy / zapatrzony / w serce rzeczy // martwą gwiazdę // czarną kroplę nieskończoności” (Objawienie ze Studium przedmiotu), dostrzegamy tu przede

nie nowym doświadczeniem nicości, odrealnienia i wyjałowienia rzeczywistości” (Lisicki, 1998: 242).

21 Przypomnijmy, że szczególnie sugestywny obraz takiej pustki znajdziemy w Epilogu zamykającym Martwa naturę $z$ wędzidłem. Zwraca na to uwage Joanna Kosturek (2010: 270). 
wszystkim obosieczne ostrze ironii. Choć pustka doskonała nie pociąga Herberta, poeta równocześnie sugeruje, że istotą świata jest nicość, nieistnienie. Paradoksalnie zagrożenie niebytem podtrzymuje sens istnienia Herbertowskiego bohatera, który dąży do konfrontacji z nicością i z „potworem Pana Cogito” prowadzi nierówną walkę 22 .

Colinas nie podejmuje takiej walki, ale też nie poddaje się rozpaczy. Wybiera kontemplację (zob. Alonso Gutiérrez, 2000: 67), szukając choćby na chwilę ulotnego poczucia harmonii. W jego wierszach jednak - trzeba przyznać - częściej dochodzi do głosu samo pragnienie i przeczucie kosmicznego ładu niż poetycko dokumentowane chwile jego doznawania. Jeszcze mniej tych szczęśliwych chwil w poezji Herberta. Twierdzi Andrzej Franaszek:

Chwile, kiedy doświadcza on harmonijnej więzi ze światem, są więc szczególne - są krótkim czasem łaski, za którą podziękowaniem staje się wiersz. Dzięki niej bohater Herberta zostaje obdarowany zdolnością dostrzeżenia - pod doskonale mu znanymi okrucieństwem natury i cierpieniem przenikającym świat - ładu, kosmicznej struktury, wypełnionej boskością (Franaszek, 2008: 204).

Krytyk przyznaje również, że „odnalezienie siebie jako elementu harmonijnej struktury świata” jest „doznaniem momentalnym” (Franaszek, 2008: 206). I dodać trzeba, że niezwykle rzadkim w poezji Herberta. W Modlitwie Pana Cogito - podróżnika powiada poeta, że „gwiazdy krążyły” i „było jak być powinno”. Nasuwa się jednak zastrzeżenie: chwile harmonii należą do przeszłości. Czy nie są wspomnieniem sztucznie wykreowanym przez pamięć, która w razie potrzeby gotowa jest podsunąć człowiekowi to, za czym najbardziej tęskni? „Działanie ironii - przypomina Wojciech Ligęza - sprawia, iż między konstrukcją intelektualną - nienaganną, czystą jak kryształ - a życiową empirią zawsze pojawiać się będzie rozziew" (Ligęza, 2005: 153).

22 Jak stwierdza Franaszek (2008: 197), odnosząc swoje spostrzeżenie nie tylko do poezji, ale również do prozy i dramatów Herberta. 
W rzeczywistości ani Colinas, ani Herbert żadnych trwałych praw harmonii w kosmosie dostrzec nie potrafią, choć bardzo ich pragną. Szczerze tęsknią za takim poczuciem harmonii, jakie stało się udziałem Mikołaja Kopernika, który pisał: „Odnaleźliśmy zatem w tym porządku zadziwiający ład świata i ustalony zharmonizowany związek między ruchem a wielkością sfer, jakiego w inny sposób odkryć niepodobna" (cyt. za Gingerich, 2008: 23). Pytanie o harmonię, będące zarazem pytaniem o los, kondycję i tożsamość człowieka, rozpływa się jednak w samotności głębokiej nocy.

Co więc daje współczesnym poetom przyglądanie się światu? Nade wszystko świadomość, że jeśli jakiekolwiek poczucie harmonii z nim jest możliwe, to jedynie doraźnie. Natura świata odzwierciedla bowiem słabość i ograniczoność człowieka. W liryce Herberta głęboko zaznacza się jeszcze poczucie obojętności świata, pomimo wspólnego z nim losu. Przyroda daje aż nadto dowodów wszechobecności cierpienia i jego bezsensu, braku porządku i zarazem bezradności. Nieuniknioność śmierci, obcość natury i samotność człowieka (Czapliński, 1998: 298) - tak można streścić lekcję, jaką daje Herbertowi świat przyrody. Dla Colinasa śmierć jako konieczne ogniwo odnawiającego się cyklu jest jednak częścią życia. Oczywiście doświadczony jest też przygnębiającym smutkiem, jaki przynosi świadomość końca wszystkiego.

Urządzenie wszechświata przede wszystkim upewnia człowieka o jego samotności wśród przerażenia i lęku. Nawet jeśli u Colinasa ktoś „nad nami płacze”, to wydaje się daleki „tam w górze” i nie dzieli naszego losu. $\mathrm{W}$ „ślepym wszechświecie” (Herbert) człowiek jest jak „ślepa kamienna masa” (Colinas), skazany na bezsensowne istnienie w ciągłym zagrożeniu i nieświadomości. Wspólne obu poetom jest poczucie pustki, która jednak dla każdego z nich ma odmienne znaczenia: Colinas potrafi w niej widzieć drogę ku harmonii, zaś Herbert zawsze przypomina o wierności konkretnej rzeczywistości, uznając mistyczne ogołocenie za pokusę łatwego i pozornego rozwiązania.

Rozdarci między pragnieniem harmonii a nieharmonijną rzeczywistością, między materialną tkanką świata a jego istnieniem duchowym, między tradycją a współczesnością - nieustan- 
nie prowadzą osobistą walkę o poczucie ładu i sensu. Poczucie bezsensu egzystencji nie jest bowiem nigdy ostateczne i decydujące, nie skłania do rozpaczy. Jest zawsze tylko etapem na drodze, na której wszechobecne cierpienie łączy człowieka z resztą natury - z całym kosmosem. To wspólny rys Colinasa i Herberta - rozczarowania nie stają się nigdy powodem, by ostatecznie zaprzeczyć istnieniu harmonii. Nawet wtedy, gdy jedyną formą łączności ze światem okazuje się uczestnictwo w takim samym cierpieniu i bezsensie.

\section{BIBLIOGRAFIA}

Alonso Gutiérrez, L. M. (1990), El corazón desmemoriado. Claves poéticas de Antonio Colinas, León: Diputación provincial de León.

Alonso Gutiérrez, L. M. (2000), Antonio Colinas, un clásico del siglo XXI, León: Universidad de León.

Barańczak, S. (2001), Uciekinier z Utopii, Wrocław: Wydawnictwo Naukowe PWN.

Cano, J. L. (1982), “Antonio Colinas, del lirismo a la meditación”, El País, 11 de julio: 7.

Colinas, A. (1990), "El arte de escribir: mi experiencia personal (Autopercepción intelectual de un proceso histórico)", Anthropos 105: 20-37.

Colinas, A. (2010), Tres tratados de armonía, Barcelona: Tusquets Editores.

Colinas, A., (2011), Obra poética completa, Madrid: Siruela.

Colinas, A. (2014), Canciones para una música silente, Madrid: Siruela.

Czapliński, P. (1998), „Śmierć, czyli o niedoskonałości”, w: A. Franaszek (wybór i wstęp), Poznawanie Herberta, Kraków: Wydawnictwo Literackie, 280-303.

Gingerich, O. (2008), Boski wszechświat, przeł. J. Włodarczyk, Warszawa: Wydawnictwo Uniwersytetu Warszawskiego.

Herbert, Z. (1993), Martwa natura z wędzidtem, Wrocław: Wydawnictwo Dolnośląskie.

Herbert, Z. (2008), Wiersze zebrane, oprac. edyt. R. Krynicki, Kraków: Wydawnictwo a5.

Fiut, A. (1998), „Język wiary i niewiary”, w: A. Franaszek (wybór i wstęp), Poznawanie Herberta 2, Kraków: Wydawnictwo Literackie, 264-279. 
Fiut, A. (2000), „Dwa spojrzenia na antyk: Kawafis i Herbert”, w: A. Franaszek (wybór i wstęp), Poznawanie Herberta 2, Kraków: Wydawnictwo Literackie, 270-294.

Franaszek, A. (2008), Ciemne źródło. Esej o cierpieniu w twórczości Zbigniewa Herberta, Kraków: Znak.

Górniak, K. (2015), „Milczenie natury. Dęby z tomu Elegia na odejście”, w: J. M. Ruszar (red.), Gq̨szcz srebrnych liści. Interpretacje wierszy Zbigniewa Herberta, Kraków: Wydawnictwo JMR Trans-Atlantyk, 183-204.

Jiménez, J. O. (1984), “Introducción”, w: A. Colinas, Poesía (1967-1981), Madrid: Visor, 9-33.

Kostkiewiczowa, T. (1998), „Komparatystyka literacka - zakres i treść pojęcia. Status naukowy badań porównawczych”, w: A. Nowicka-Jeżowa (red.), Badania porównawcze. Dyskusja o metodzie. Radziejowice 6-8lutego 1997 r., Izabelin: Świat Literacki, 11-16.

Kosturek, J. (2010), „Żeby tylko nie anioł... Konkret i abstrakcja w poezji Zbigniewa Herberta", w: J. M. Ruszar (red.), Pojęcia kiełkujace z rzeczy. Filozoficzne inspiracje twórczości Zbigniewa Herberta, Kraków: Wydawnictwo Platan, 233-277.

Ligęza, W. (2001), „Elegie Zbigniewa Herberta”, w: M. Woźniak-Łabieniec, J. Wiśniewski (red.), Twórczość Zbigniewa Herberta, Kraków: Universitas, 27-50.

Ligęza, W. (2005), „Historia muzyki według Pana Cogito”, w: W. Ligęza, M. Cicha (red.), Portret z początku wieku. Twórczość Zbigniewa Herberta - kontynuacje i rewizje, Lublin: Gaudium, 153-181.

Lisicki, P. (1998), „Puste niebo Pana Cogito”, w: A. Franaszek (wybór i wstęp), Poznawanie Herberta, Kraków: Wydawnictwo Literackie, 241-263.

Marí, A. (1990), "Hacia el orden y la locura de las estrellas", Anthropos 105: 57-59.

Markiewicz, H. (1989), „Literatura a mity”, w: H. Markiewicz, Literaturoznawstwo ijego sąsiedztwa, Warszawa: PWN, 64-97.

Opacka-Walasek, D. (2005), „O «nieprzerwanym szumie ogromnej klepsydry». Obrazy czasu w poezji Zbigniewa Herberta - kontynuacje i rewizje”, w: W. Ligęza, M. Cicha (red.), Portret z początku wieku. Twórczość Zbigniewa Herberta - kontynuacje i rewizje, Lublin: Gaudium, 110-128.

Potkański, J. (2002), „Rola przerzutni w wierszach Zbigniewa Herberta”, w: E. Czaplejewicz, W. Sadowski (red.), Herbert. Poetyka, wartości i konteksty, Warszawa: Wydawnictwo DiG, 25-34. 
Przybylski, R. (1998), „Między cierpieniem a formą”, w: A. Franaszek (wybór i wstęp), Poznawanie Herberta, Kraków: Wydawnictwo Literackie, 80-127.

Sepúlveda, J. (1997), "Notas de lectura de Jardín de Orfeo", w: A. Colinas, El viaje hacia el centro, Madrid: Calambur, 237-243.

Stelmaszczyk, B. (2001), „Epilog na odejście. Ostatnie przesłanie poetyckie Herberta”, w: M. Woźniak-Łabieniec, J. Wiśniewski (red.), Twórczość Zbigniewa Herberta, Kraków: Universitas, 315-330. 